\title{
Doświadczenie użytkownika w erze streamingu - analiza komparatystyczna serwisów VoD obecnych na polskim rynku
}

\section{Ewolucja oglądania filmów}

Ruchomy obraz towarzyszy człowiekowi już od prawie dwóch wieków. W tym czasie zaszła znaczna transformacja, determinowana przemianami w kulturze i technice. W ciągu lat, dzięki rozwijającym się nowym mediom, zmieniały się sposoby i okoliczności oglądania filmów. Zmieniały się także same filmy — od krótkich, kilkuminutowych materiałów rejestrujących realne wydarzenia, przez nieco dłuższe formy oparte na wymyślonych historiach, doszliśmy do realizowanych z rozmachem parogodzinnych spektakli, które obfitują w efekty specjalne.

Pierwsze projekcje funkcjonowały jako imprezy objazdowe - odbywały się tam, gdzie można było ustawić ekran i zaciemnić pomieszczenie ${ }^{1}$. Za datę narodzin kina uznaje się 28 grudnia 1895 roku, kiedy to bracia Lumière zorganizowali pierwszy publiczny i zarazem płatny pokaz we Francji ${ }^{2}$. Mimo że od strony technicznej nie byli prekursorami kinematografii, to właśnie oni najwcześniej umożliwili dostęp szerszej publiczności do tego rodzaju rozrywki ${ }^{3}$. Do 1910 roku w Europie i Ameryce powsta-

\footnotetext{
1 National Science and Media Museum, A very short history of cinema, https://blog.scienceandmediamuseum.org.uk/very-short-history-of-cinema (dostęp: 13.05.2020).

2 Narodziny techniki filmowej i kinowej, https://www.historiasztuki.com.pl/strony/015-00-01-FILM-TECHNIKA.html (dostęp: 13.05.2020).

3 Ł. Michalik, 120 lat kina. Jak zmieniała się technologia, dzięki której oglądamy filmy?, https://gadzetomania.pl/57136,120-lat-kina-jak-zmieniala-sie-technologia-dzieki-ktorej-ogladamy-filmy (dostęp: 12.05.2020).
} 
ły tysiące sal kinowych. Na całym świecie można było obserwować ekspansję coraz bardziej nowoczesnych kin. XX wiek to również pojawienie się telewizji. Pierwszą, realizowaną na żywo, transmisję ruchomych obrazów zademonstrował w 1926 roku John Logie Baird ${ }^{4}$. Oglądanie, które kiedyś dostępne było tylko w specjalnie do tego przeznaczonym miejscu, przeniosło się w końcu do przestrzeni domowej. Z biegiem czasu powstawały nowe sposoby dystrybucji filmów. Pojawiły się wypożyczalnie kaset VHS i płyt DVD. W większości nie wytrzymały one jednak konkurencji, będącej konsekwencją intensywnego rozwoju usług internetowych. Rewolucja cyfrowa spowodowała powstanie kanałów dystrybucji dających większy, a zarazem wygodniejszy dostęp do oferty kinematograficznej. Przełom XX i XXI wieku to okres dominacji cyfrowej dystrybucji i często nielegalnego ściągania treści wideo. Przemysł kultury nazwał te nielegalne w sensie prawnym praktyki piractwem. Jak pisze Anna Anetta Janowska, produkty płatne zaczęły być wypierane z rynku przez tę „nieautoryzowaną i masową wymianę $\mathrm{w}$ sieci”" Tym samym nastąpiło „osłabienie pozycji przedsiębiorstw dominujących dotychczas na poszczególnych rynkach przemysłów kultury, co natomiast stworzyło możliwość nowym podmiotom na wypełnienie zaistniałej luki, szczególnie w obrębie dystrybucji”’ Tę właśnie lukę na rynku filmowym wypełnił tak zwany streaming.

\section{Era serwisów streamingowych}

Serwisy streamingowe to serwisy, które za pomocą cyfrowego przekazu obrazu i dźwięku dostarczają treść do użytkownika ${ }^{7}$. Jedną z usług, które mogą oferować, jest tak zwane video on demand, czyli wideo na żądanie, w skrócie VoD. Janowska opisuje początek zjawiska, które jest wypadkową wprowadzenia tego systemu dystrybucji treści, a więc „dematerializacji produktów przemysłów kultury”, niebędących już nierozerwalnie związanymi z konkretnymi nośnikami ${ }^{8}$. Konsekwencją tego procesu, jak również faktu rewolucji cyfrowej jest rezygnacja z własności na rzecz dostępu' Kupujący zmienili się w użytkowników, którzy zamiast posiadać korzystają. Wraz z pojawieniem się serwisów streamingowych można obserwować wytworzenie się

${ }^{4}$ B.D. Inglis, G.D. Couples, John Logie Baird and the secret in the box: The undiscovered story behind the world's first public demonstration of television, „Proceedings of the IEEE” 2020, nr 108, s. 1371.

5 A. Janowska, Przemysł kultury w erze dostępu, „Kolegium Zarządzania i Finansów. Zeszyt Naukowy" 2017, nr 158, s. 188.

6 Ibidem, s. 189.

7 N. Bryl, Streaming w kulturze - uwagi wstępne, „Studia ad Bibliothecarum Scientiam Pertinentia” 2018, nr 16, s. 129.

8 A. Janowska, op. cit., s. 184.

9 J. Rifkin, Wiek dostępu: nowa kultura hiperkapitalizmu, w której płaci się za każda chwilę życia, Wrocław 2003, cyt. za: A. Janowska, op. cit., s. 190. 
nowego rodzaju odbiorcy ${ }^{10}$. Dzisiejszy widz nie jest już uzależniony od konieczności czekania przed telewizorem na daną godzinę, żeby obejrzeć ulubiony program. Nie musi też jechać do wypożyczalni, żeby zdobyć płytę bądź kasetę z danym filmem. Nowe technologie zapewniają dostęp do treści multimedialnych w dogodnym dla użytkownika czasie i na wybranym przez niego urządzeniu - telewizorze, komputerze, tablecie czy smartfonie. To on podejmuje decyzję co do tego, co i gdzie w danej chwili będzie oglądał.

\section{Konkurencja a wybór}

Dynamiczny lifestyle nowoczesnego widza sprawia, że jego czas wolny jest bardzo ograniczonym zasobem i musi go efektywnie wykorzystać. Żyjemy w czasach kultury nadmiaru, kultury przeładowania. Różne formy rozrywki i odpoczynku od natłoku informacji są oferowane z każdej strony. Dawniej kina konkurowały o klientów głównie $\mathrm{z}$ innymi kinami i teatrami. Obecnie, w erze globalizacji, w świecie łatwego dostępu do technologii, wyzwaniem jest zdobycie uwagi widza ${ }^{11}$, bo zabiega się o nią z każdej strony. Reed Hastings, CEO firmy Netflix, sformułował twierdzenie o bardzo szerokim zakresie działań, które podejmują ludzie w celu zrelaksowania się. Każda z tych czynności jest potencjalną konkurencją mogącą przeciągnąć odbiorcę na swoją stronę ${ }^{12}$. Nie są to więc tylko inne kanały w obrębie kultury audiowizualnej, takie jak telewizja, kino, YouTube czy TikTok, ale też czytanie książek, granie w gry komputerowe czy przeglądanie wiadomości. Hastings pokusił się nawet o stwierdzenie, że głównym rywalem Netfliksa jest $\operatorname{sen}^{13}$. Z tego powodu platformy streamingowe mają znacznie utrudnione zadanie w grze, w której walutami są abonament i uwaga użytkownika. Muszą bowiem wygrać tak zwany moment of truth - moment prawdy ${ }^{14}$. W marketingu tym sformułowaniem określa się chwile, które szczególnie mocno wpływają na ocenę danej marki czy usługi. Są to najważniejsze składniki doświadczenia klienta, ponieważ są najmocniej zapamiętywane i wpływają na ostateczną decyzję podejmowaną przez konsumenta, który został postawiony przed wyborem ${ }^{15}$.

10 M. Golińska-Konecko, Stare media wobec nowych technologii. Ewolucja telewizji w Polsce, „Zeszyty Naukowe Gdańskiej Szkoły Wyższej” 2018, nr 3, s. 203.

11 N. Bryl, op. cit., s. 136.

12 R. Raphael, Netflix CEO: Reed Hastings: Sleep is our competition, https://www.fastcompany. com/40491939/netflix-ceo-reed-hastings-sleep-is-our-competition (dostęp: 12.05.2020).

13 Ibidem.

14 M. Levinson, Netflix: Winning moments of truth?, https://medium.com/@maxlevinson/netflix-winning-moments-of-truth-113cc7884909 (dostęp: 13.05.2020).

15 J. Pogorzelski, Momenty prawdy i punkty kontaktu, http://jacekpogorzelski.pl/momenty-prawdy-i-punkty-kontaktu (dostęp: 13.05.2020). 


\section{Doświadczenie użytkownika a jego uwaga}

W 1996 roku Bill Gates opublikował artykuł, którego tytuł brzmiał Content is king ${ }^{16}$, przewidując tym samym, jak ważna stanie się treść w Internecie. Nie można zaprzeczyć, że to właśnie dostępność do konkretnych treści odgrywa kluczową rolę w sukcesie internetowych serwisów wideo. Obecne na takich platformach filmy i seriale są znaczącym elementem ułatwiającym zdobycie zainteresowania użytkowników. Jednak dostęp do jakościowych filmów jest ograniczony. Nowe tytuły są oczywiście wciąż produkowane, ale musi upłynąć trochę czasu, żeby największe produkcje mogły trafić do przestrzeni internetowej, w związku z czym ich liczba jest w danym momencie skończona. Ponadto nie są one skumulowane w obrębie jednej platformy, a raczej rozbite między konkurujące z sobą serwisy. Występuje więc konieczność przywiązania użytkownika do konkretnej marki i nakłonienia go, by został z nią, płacił za subskrypcję i korzystał ze wszystkich dzieł, które dany serwis ma do zaoferowania, również tych, do których prawa są tańsze czy które są oryginalnym produktem platformy. W związku z tym, oprócz oferowania gamy filmów i seriali, dostawcy zajmujący się usługami wideo muszą też zapewnić użytkownikowi pozytywne doświadczenie.

„Suma wszystkich doświadczeń, emocji i przeżyć klienta, które wiążą się z daną marką" ${ }^{17}$, określana jest terminem customer experience (CX). Na to całościowe postrzeganie konkretnej firmy wpływają zatem wszystkie interakcje oraz odczucia, które były nimi spowodowane. W swojej podróży do określonego celu klient przechodzi przez poszczególne miejsca, nazwane punktami styku ${ }^{18}$. Natomiast w momencie, w którym uwaga skupiona jest na decydującym punkcie, czyli korzystaniu z produktu, usługi czy rozwiązania, mówi się już o doświadczeniu użytkownika ${ }^{19}$. Doświadczenie użytkownika (ang. user experience - UX) można w skrócie zdefiniować jako „całość wrażeń użytkownika w kontakcie z aplikacją, programem czy stroną WWW"20. Dobre UX ułatwia więc zaangażowanie odbiorców i sprawia, że zawartość jest łatwo dostępna ${ }^{21}$, podczas gdy złe zabija treśćc ${ }^{22}$. Z badań przeprowadzonych przez PwC w marcu 2019 roku wynika, że konsumenci pragną serwisów, które są proste i intuicyjne. Takich, po których łatwo jest nawigować w celu znale-

16 B. Gates, Content is king, 1996, cyt. za: H. Evans, Content is king - essay by Bill Gates 1996, https:// medium.com/@HeathEvans/content-is-king-essay-by-bill-gates-1996-df74552f80d9 (dostęp: 12.05.2020).

17 A. Kita, Dlaczego Customer Experience to nie User Experience?, https://www.thinkle.pl/2019/08/27/ dlaczego-cx-to-nie-ux/ (dostęp: 22.11.2020).

18 A. Urbański, L. Dziewa, Tworzenie doświadczeń klientów, Gliwice 2020, s. 93.

19 A. Kita, op. cit.

20 The Pathfinders, 6 glównych obszarów User Experience - czym jest UX Kompas? https://medium. com/@thepathfinderspl/ux-kompas-1f449b67d860 (dostęp: 12.05.2020).

${ }^{21} \mathrm{PwC}$, Streaming ahead. Making UX + content strategy work together, https://www.pwc.com/us/en/ services/consulting/library/pdf/2019-tmt-cis-content-is-king.pdf (dostęp: 11.05.2020).

${ }^{22} \mathrm{~L}$. Rice, Content is king, but UX is queen, https://www.linkedin.com/pulse/content-king-uxqueen-elizabeth-rice (dostęp: 11.05.2020). 
zienia właściwego filmu czy serialu ${ }^{23}$. Steve Krug - specjalista od projektowania doświadczeń użytkownika - sformułował regułę, uważaną za jedną z najważniejszych zasad w świecie UX. Brzmi ona Don't make me think, czyli „nie każ mi myśleć”24. Im dłużej bowiem ludzie będą musieli myśleć nad czymś, co powinno być instynktowne, tym istnieje większe prawdopodobieństwo, że zrezygnują z danej usługi i następnym razem wybiorą produkt konkurencji.

Daniel Kahneman jest autorem teorii o dwóch systemach operacyjnych w mózgu każdego człowieka. Zgodnie z nią istnieją tak zwane System 1 i System 2. Przez znacznie większą część czasu ludzie używają Systemu 1, który jest szybszy, automatyczny i intuicyjny. Nie wymaga on od człowieka głębszych rozważań, a tym samym nie jest męczący. System 2 natomiast włącza się w momencie, gdy trzeba przeanalizować i ocenić jakąśs sytuację. Charakteryzuje się on logiką, jest świadomy i kontrolowany, ale też powoduje szybsze zmęczenie ${ }^{25}$. Przeciętnie $\mathrm{w}$ ciągu dnia każdy $\mathrm{z}$ nas podejmuje około 35 tysięcy decyzjii ${ }^{26}$. Gdybyśmy musieli świadomie przetwarzać każdą z nich, nasz mózg miałby duży problem, żeby poprawnie funkcjonować. $Z$ tego powodu ważne jest, aby tworzyć produkty, które będą intuicyjne i nie będą wymagały udziału Systemu 2. Dobra platforma ma więc dobrze zaprojektowane doświadczenie użytkownika.

\section{Analiza komparatystyczna}

Liczba płatnych serwisów VoD dostępnych na rynku polskim z roku na rok rośnie. Nie sposób ich wszystkich porównać w formie krótkiego artykułu, bo wymagałoby to szerokich badań i wnikliwej ewaluacji. Analizie poddane zostaną więc aplikacje mobilne najważniejszych czterech dostawców oferujących usługę wideo na żądanie. Wzrost znaczenia urządzeń mobilnych $\mathrm{w}$ konsumpcji treści wideo jest bezprecedensowy ${ }^{27}$. $\mathrm{Z}$ uwagi na rosnącą rolę urządzeń mobilnych ${ }^{28}$ interesuje nas UX z perspektywy urządzeń mobilnych z ekranami dotykowymi - smartfonów i tabletów. Rozwiązania UX aplikacji mobilnych różnią się od UX aplikacji desktopowych (czyli programów kom-

23 PwC, op. cit.

24 S. Krug, Don't Make Me Think, Revisited: A Common Sense Approach to Web Usability, [bmw] 2013, s. 50.

25 A. Groenewegen, Kahneman fast and slow thinking explained, https://suebehaviouraldesign.com/ kahneman-fast-slow-thinking (dostęp: 12.05.2020).

26 Ibidem.

27 PwC, Wideo: więcej, szybciej, lepiej. Jak cyfrowa rewolucja zmienia rynek treści wideo, https:// www.pwc.pl/pl/pdf/pwc-raport-wideo-2017.pdf (dostęp: 11.05.2020).

28 M. Bednarzewski, Ewolucja postaw konsumentów w Polsce wobec sposobów korzystania z rozrywki filmowej, [w:] Kreatywność i innowacyjność w erze cyfrowej, red. A. Zorska, M. Molęda-Zdziech, B. Jung, Warszawa 2014, s. 179. 
puterowych) i webowych (działających w przestrzeni Internetu) ${ }^{29}$. Smartfony i tablety są po prostu młodsze; ich interfejsy nie są jeszcze tak przemyślane jak te, które szlifowane były na komputerach przez wiele lat ich używania. Ponadto laptopy i komputery kojarzą się z pracą i nie są tak wygodne jak urządzenia mobilne, z których można korzystać, odpoczywając na kanapie albo podczas jazdy komunikacją miejską.

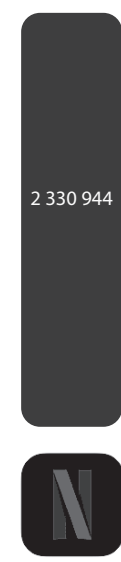

Netflix
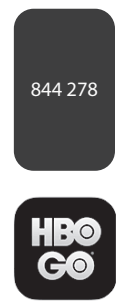

$\mathrm{HBO} G \mathrm{O}$
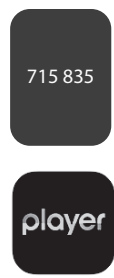

Player

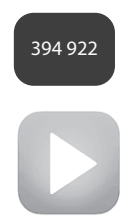

IPLA mobile

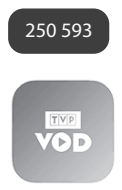

TVP VOD

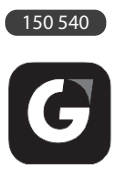

$\mathrm{nc}+\mathrm{Go}$

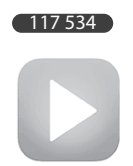

IPLA PC
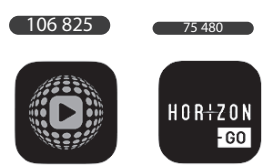

Cyfrowy Horizon GO Polsat

Wykres 1. Liczba użytkowników VoD w Polsce (luty 2020 r.) na podstawie badań Genius/PBI dla serwisu wirtualnemedia.pl

Porównane zostaną aplikacje dostawców, którzy dominują na rynku krajowym pod względem liczby subskrybentów. $Z$ tego względu skonfrontowane zostaną rozwiązania w aplikacjach mobilnych takich serwisów jak Netflix i HBO GO. Celem kontrastu poglądowego zostanie to zestawione z polskim liderem, czyli z platformą Player, należącą do Grupy TVN. Wzięty pod uwagę zostanie również serwis Amazon Prime Video, który na polskim rynku jest stosunkowo nowy. Wprowadza on natomiast rozwiązania nieobecne u konkurencji. Z uwagi na obszerność tematu analizowane elementy będą dotyczyły tylko narzędzi stosowanych przy samym odtwarzaczu wideo ${ }^{30}$.

29 Jest to również spowodowane podejściem do projektowania. Design responsywny ma na celu tworzenie rozwiązań, które zapewniają optymalne wrażenia wizualne na różnych platformach, uwzględniając rozmiar urządzenia, na którym wyświetlana jest treść. To, co nie jest tworzone zgodnie z ideą responsywności, może nie wyświetlać się poprawnie na wszystkich urządzeniach, w końcu ich różnorodność jest bardzo duża. Koncepcja ta jest bardzo istotna w przypadku stron internetowych serwisów, które dodatkowo nie oferują specjalistycznych aplikacji na urządzenia mobilne. Ten artykuł będzie się natomiast skupiał właśnie na aplikacjach mobilnych i doświadczeniu, które wynika $\mathrm{z}$ ich użytkowania.

${ }^{30}$ Niniejszy artykuł jest tylko wstępną analizą eksploracyjną, która ma na celu przegląd rozwiązań zastosowanych przez firmy dążące do zredukowania powodów, przez które użytkownik może chcieć 


\section{Start oglądania}

Na platformie Netflix odtwarzanie wideo zaczyna się od razu, gdy tylko odbiorca wybierze dany materiał. Podobnie ma to miejsce w wypadku Playera (w wersji płatnej). Z kolei Amazon Prime Video raz na jakiś czas pokazuje zapowiedzi innych filmów czy seriali, daje jednak możliwość pominięcia takiego zwiastuna, w myśl zasady, że użytkownik, który płaci za daną usługę, płaci również za to, żeby pozbyć się reklam. HBO GO podobnie jak Prime Video pokazywał kiedyś krótkie materiały promocyjne, nie udostępniał za to możliwości ich pominięcia, co spotykało się z negatywną opinią korzystających z tego serwisu subskrybentów. Obecnie nie prowadzi już takiej praktyki.

\section{Streszczenie poprzednich odcinków}

Tak zwany recap ${ }^{31}$ pojawia się na początku niektórych seriali. Jego zadaniem jest przypomnienie użytkownikowi, co działo się w ostatnich epizodach, by nie zgubił wątku. Opcja ta przydatna jest w sytuacji, gdy widz ogląda odcinki w pewnym odstępie czasu - tak jak to się dzieje w przypadku tradycyjnej telewizji, gdzie ten format jest często obecny. Natomiast jeśli ogląda kilka epizodów z rzędu, nie ma potrzeby, aby za każdym razem przypominał sobie, co było poprzednio. Wystąpienie takiego streszczenia zależne jest od konkretnego serialu. Jeśli już się pojawia, to zarówno Netflix, jak i Amazon Prime dają możliwość jego pominięcia. HBO GO pokazuje recap zawsze, jeśli tylko jest dostępny. Nie istnieje przycisk, który pozwoliłby to ominąć. Również Player nie oferuje takiej opcji.

\section{Intro}

Napisy początkowe, czy tak zwana czołówka, to element obecny w niemal każdym filmie i serialu. Jedne są bardzo krótkie i ograniczają się do pokazania tytułu, inne, jak choćby czołówka serialu Gra o Tron (trwająca 1 minutę i 40 sekund), są dość rozbudowane. Konieczność oglądania tej samej sekwencji tytułowej za każdym razem, gdy włącza się kolejny odcinek, niewątpliwie jest męcząca dla widza, który po pewnym czasie może już mieć jej dość. W takiej sytuacji pomocne okazały się Netflix i Amazon Prime, oferujące wybór - obejrzeć lub pominąć. Zmniejsza to wysiłek użytkownika i przyspiesza osiągnięcie celu, jakim jest dostęp do programu. Tekst na przycisku

opuścić daną aplikację. W rozszerzeniu badania warto byłoby skupić się na wszystkich rozwiązaniach z zakresu UX zastosowanych w aplikacjach wymienionych firm.

31 Recap to podsumowanie tego, co działo się wcześniej w serialu. 
nie mówi tylko „pomiń”, ale „pomiń wstęp/czołówkę". Jest to dobra praktyka z perspektywy UX, ponieważ wyraźnie komunikuje zamierzoną akcję i jej skutek ${ }^{32}$. HBO GO i Player wyboru nie dają.

\section{Pasek postępu}

Pasek postępu używany jest głównie do nawigowania na osi czasu — jego design może wspomóc bądź utrudnić tę czynność. W aplikacjach Netfliksa i Amazon Prime Video projektanci zdecydowali się wprowadzić ułatwienie w postaci miniaturek scen, które pojawiają się nad paskiem podczas przewijania. W przypadku HBO GO można zauważyć brak podobnego rozwiązania. Niemożliwe jest tu również przesunięcie paska postępu o kilka sekund w stosunku do miejsca, w którym widz jest obecnie. Z kolei Player jako jedyny z całej czwórki powiększa pasek nawigacji przy dotknięciu palcem.

\section{Przewijanie}

Opcja przewijania wideo o 10 (lub 15) sekund w przód lub w tył umożliwia widzowi łatwiejszy dostęp, jeśli konkretną scenę chce zobaczyć jeszcze raz. Zarówno na platformie Netflix, jak i Amazon Prime Video przyciski te są umiejscowione na środku ekranu, zaraz obok „odtwórz/zatrzymaj”, co jest dobrym rozwiązaniem z perspektywy wydajności i użyteczności, ponieważ użytkownik nie jest zmuszony do ich poszukiwania $^{33}$. HBO GO w aplikacji mobilnej oferuje tylko możliwość cofania. Przycisk odpowiadający za tę akcję jest jednak mały i został umieszczony w lewym dolnym rogu. W serwisie Player taka funkcja jest niedostępna.

\section{Wznowienie odtwarzania serii}

Opcja automatycznego zapamiętywania ułatwia obcowanie użytkownika z serwisem, jednocześnie sprawiając, że nie musi szukać miejsca, w którym przerwał oglądanie. Netflix bezpośrednio przekierowuje odbiorcę ze strony głównej do właściwego momentu w konkretnym odcinku. Natomiast Amazon Prime dodaje jeden przystanek na ścieżce użytkownika, dając mu możliwość wznowienia od uprzednio skończonego fragmentu bądź oglądania od początku. Tak samo postępują HBO GO i Player.

${ }^{32}$ N. Babich, 7 basic rules for button design, https://uxplanet.org/7-basic-rules-for-button-design63dcdf5676b4 (dostęp: 20.07.2020).

${ }^{33}$ Ibidem. 


\section{Następny odcinek}

Przejście do następnego odcinka bezpośrednio z odtwarzacza wideo na platformie Netflix możliwe jest na trzy sposoby. Przede wszystkim pod paskiem postępu znajduje się przycisk, który natychmiast przenosi użytkownika do następnej części. Możliwe jest również rozwinięcie listy ze wszystkimi epizodami i wybór właściwego. Ponadto występuje tu funkcja automatycznego odtwarzania, w wypadku której Netflix po 5 sekundach rozpoczyna odtwarzanie kolejnej części. Amazon Prime Video i HBO GO także mają przyciski „następny odcinek”, choć w przypadku HBO GO przycisk nie jest opisany, tylko przedstawiony ikonograficznie za pomocą strzałki, co może utrudnić zrozumienie przekazu. HBO GO dodatkowo ma ikonę strzałki, kierującą do poprzedniego odcinka. Oba wymienione serwisy mają opcję autoodtwarzania po skończonym odcinku. Z kolei w serwisie Player po skończonym programie odtwarzacz wideo wyłącza się, nie ma funkcji wyboru następnego odcinka z poziomu ekranu.

\section{Czy dalej oglądasz?}

To wiadomość, która dla wielu użytkowników Internetu, stała się już pewnego rodzaju memem ${ }^{34}$. Pojawia się, jak piszą przedstawiciele Netfliksa, do dwóch minut od rozpoczęcia trzeciego odcinka, po tym, jak widz obejrzał dwa odcinki z rzędu bez interakcji z panelem kontrolnym ${ }^{35}$. Ma to być spowodowane troską o klienta firma chce zapobiec zużyciu zbędnych danych internetowych. Działanie to wydaje się więc uzasadnione. Netflix nie wprowadził jednak możliwości wyłączenia owej wiadomości, co może spowodować rozdrażnienie subskrybentów, którzy uprawiają binge-watching ${ }^{36}$. W tej sytuacji taki komunikat jest bezcelowy. Informacja jest charakterystyczna dla platformy Hastingsa, nie pojawia się u pozostałych.

\section{Regulacja głośności}

Netflix i Amazon Prime uwzględniają na ekranie odtwarzacza pasek regulacji głośności. HBO i Player tego nie robią. Nie jest to jednak szczególnie duży mankament,

\footnotetext{
${ }^{34}$ Mem internetowy to gatunek wypowiedzi internetowej, komunikat obrazkowy zbudowany na podstawie schematu konstrukcyjnego wykorzystującego skonwencjonalizowane elementy związane $\mathrm{z}$ kulturą i historią Internetu.

35 https://help.netflix.com/en/node/114059 (dostęp: 12.05.2020).

36 Binge-watching to zjawisko kompulsywnego oglądania seriali, charakteryzujące się oglądaniem po kilka odcinków serialu z rzędu.
} 
patrząc z perspektywy urządzeń mobilnych, które są przecież wyposażone w fizyczne przyciski, które mają za zadanie spełniać tę funkcję.

\section{Napisy i dostosowanie dźwięku}

Język napisów i język dźwięku Netflix ma połączone w obrębie jednej funkcji, dostępnej po kliknięciu w przycisk pod paskiem postępu. Na takie samo rozwiązanie zdecydowali się projektanci HBO GO i Amazon Prime Video, zmieniając tylko lokalizację przycisku na prawy górny róg. Co ważne, można tutaj zaobserwować projektowanie zorientowane na użytkownika. Netflix i Amazon Prime zapewniają bowiem możliwość włączenia audiodeskrypcji (jest dostępna w języku angielskim, choć nie we wszystkich materiałach), czyli dodatkowej ścieżki opisowej, która umożliwia i ułatwia oglądanie filmu osobom niewidomym. W przerwach pomiędzy dialogami dopowiada ona, co dzieje się na ekranie. Opisuje postawę bohaterów, ich mimikę, gesty czy istotne elementy fabuły. To narzędzie na nowo otworzyło przed niewidomymi świat filmów i seriali ${ }^{37}$. W HBO nie znajdziemy takiej funkcji, istnieje natomiast opcja dopasowania wielkości napisów, przydatna dla osób starszych i słabowidzących. Player jako polska platforma, z polskimi materiałami, nie pozwala na zmianę języka, napisów czy włączenie audiodeskrypcji.

\section{Rozmiar obrazu}

Dopasowanie rozmiaru odtwarzanego obrazu jest możliwe zarówno na Netfliksie, jak i w usłudze Amazon Prime. Tutaj rewolucyjne jest jednak rozwiązanie HBO GO. Ma on bowiem tryb „obraz w obrazie”, który pozwala na dostęp do innych treści w trakcie oglądania materiału. Funkcję tę do swojej aplikacji wprowadził również Netflix, natomiast nie jest ona dostępna dla wszystkich. Jej obecność zależna jest od systemu operacyjnego urządzenia mobilnego, z którego korzystają użytkownicy. Player zaś nie ma dostępnego żadnego narzędzia związanego z tym elementem.

\section{X-Ray}

Zawiera informacje kontekstowe na temat aktualnie odtwarzanej sceny — mogą to być takie dane, jak obecni w scenie aktorzy, muzyka czy ciekawostki na temat konkretnych ujęć. Całość dostępna jest bez konieczności przerywania odtwarzania. Jest

37 A. Nyziak, Jak niewidomi ogladaja filmy, http://swiatlekarza.pl/niewidomi-ogladaja-filmy (dostęp: 14.05.2020). 
to znaczne ułatwienie dla użytkowników, którzy nie muszą zatrzymywać wideo, żeby w innych źródłach znaleźć interesujące ich wiadomości. Dodatkowo X-Ray można wykorzystać do nawigowania po scenach. Jest cechą dystynktywną dla Amazon Prime Video. Żadna z pozostałych analizowanych platform nie zdecydowała się na wprowadzenie takiego rozwiązania.

\section{Wyjście z odtwarzacza}

Najbardziej widoczny przycisk powrotu na stronę główną ma HBO GO. Netflix i Player mają znak ikoniczny w prawym górnym rogu, natomiast Amazon Prime ma tutaj najmniej wyraźne rozwiązanie. Strzałka powrotu pojawia się bowiem nad opcją $X$-Ray, przez co może być lekko ukryta przed wzrokiem widza.

Tabela 1. Porównanie dostępnych opcji

\begin{tabular}{|c|c|c|c|c|}
\hline & Netflix & $\mathrm{HBO}$ GO & TVN Player & $\begin{array}{c}\text { Amazon Prime } \\
\text { Video }\end{array}$ \\
\hline $\begin{array}{l}\text { Natychmiastowy } \\
\text { start oglądania }\end{array}$ & Tak & Tak & Tak & Tak \\
\hline $\begin{array}{l}\text { Materiały pro- } \\
\text { mocyjne przed } \\
\text { startem }\end{array}$ & Nie & $\begin{array}{l}\text { Nie (kiedyś poja- } \\
\text { wiał się zwia- } \\
\text { stun, którego } \\
\text { nie można było } \\
\text { pominąć) }\end{array}$ & $\begin{array}{l}\text { Nie (przynaj- } \\
\text { mniej w wersji } \\
\text { płatnej nie } \\
\text { powinny się po- } \\
\text { jawiać, choć co } \\
\text { innego twierdzą } \\
\text { użytkownicy) }\end{array}$ & $\begin{array}{l}\text { Tak, pojawiają } \\
\text { się czasami, ale } \\
\text { można pominąć }\end{array}$ \\
\hline $\begin{array}{l}\text { Pojawiający się } \\
\text { recap jest moż- } \\
\text { liwy do pomi- } \\
\text { nięcia }\end{array}$ & Tak & Nie & Nie & Tak \\
\hline $\begin{array}{l}\text { Intro możliwe do } \\
\text { pominięcia }\end{array}$ & Tak & Nie & Nie & Tak \\
\hline $\begin{array}{l}\text { Podgląd scen na } \\
\text { pasku }\end{array}$ & Tak & Nie & Nie & Tak \\
\hline $\begin{array}{l}\text { Możliwość prze- } \\
\text { sunięcia paska } \\
\text { postępu o kilka } \\
\text { sekund }\end{array}$ & Tak & Nie & Tak & Tak \\
\hline $\begin{array}{l}\text { Pasek postępu } \\
\text { powiększa się } \\
\text { przy dotknięciu } \\
\text { palcem }\end{array}$ & Nie & $\mathrm{Nie}$ & Tak & $\mathrm{Nie}$ \\
\hline
\end{tabular}




\begin{tabular}{|c|c|c|c|c|}
\hline $\begin{array}{l}\text { Obecność } \\
\text { przycisków do } \\
\text { przewijania }\end{array}$ & $\begin{array}{l}\text { Tak (10 sekund } \\
\text { w przód i w tył) }\end{array}$ & $\begin{array}{c}\text { Tak, ale tylko } 15 \\
\text { sekund w tył }\end{array}$ & $\mathrm{Nie}$ & $\begin{array}{l}\text { Tak (10 sekund } \\
\text { w przód i w tył) }\end{array}$ \\
\hline $\begin{array}{l}\text { Automatyczne } \\
\text { zapamiętywanie } \\
\text { miejsca, w któ- } \\
\text { rym widz prze- } \\
\text { rwał oglądanie }\end{array}$ & Tak & Tak & Tak & Tak \\
\hline $\begin{array}{l}\text { Przejście do na- } \\
\text { stępnego odcinka } \\
\text { bezpośrednio } \\
\text { z odtwarzacza }\end{array}$ & $\begin{array}{c}\text { Tak - przy- } \\
\text { cisk „następny } \\
\text { odcinek” oraz } \\
\text { rozwijana lista } \\
\text { wszystkich od- } \\
\text { cinków }\end{array}$ & $\begin{array}{l}\text { Tak - przycisk } \\
\text { nie jest opisany, } \\
\text { tylko oznaczany } \\
\text { strzałką; możliwe } \\
\text { jest również } \\
\text { przejście do } \\
\text { poprzedniego } \\
\text { odcinka }\end{array}$ & $\mathrm{Nie}$ & $\begin{array}{c}\text { Tak - przycisk } \\
\text { „następny odci- } \\
\text { nek” }\end{array}$ \\
\hline $\begin{array}{l}\text { Automatyczne } \\
\text { odtwarzanie na- } \\
\text { stępnego odcinka }\end{array}$ & Tak & Tak & $\mathrm{Nie}$ & Tak \\
\hline $\begin{array}{l}\text { Wiadomość „czy } \\
\text { dalej oglądasz?” }\end{array}$ & Tak & $\mathrm{Nie}$ & $\mathrm{Nie}$ & $\mathrm{Nie}$ \\
\hline $\begin{array}{l}\text { Obecność paska } \\
\text { regulacji głośno- } \\
\text { ści na ekranie } \\
\text { odtwarzacza }\end{array}$ & Tak & Nie & $\mathrm{Nie}$ & Tak \\
\hline $\begin{array}{l}\text { Możliwość } \\
\text { dostosowania } \\
\text { języka napisów } \\
\text { i dźwięku }\end{array}$ & Tak & Tak & $\mathrm{Nie}$ & Tak \\
\hline $\begin{array}{l}\text { Możliwość włą- } \\
\text { czenia audiode- } \\
\text { skrypcji }\end{array}$ & Tak & Nie & $\mathrm{Nie}$ & Tak \\
\hline $\begin{array}{l}\text { Dopasowanie } \\
\text { rozmiaru odtwa- } \\
\text { rzanego obrazu }\end{array}$ & $\begin{array}{c}\text { Tak - obecny } \\
\text { tryb „obraz } \\
\text { w obrazie” (choć } \\
\text { nie na wszystkich } \\
\text { urządzeniach) }\end{array}$ & $\begin{array}{c}\text { Tak - obecny } \\
\text { tryb „obraz } \\
\text { w obrazie” }\end{array}$ & $\mathrm{Nie}$ & Tak \\
\hline $\begin{array}{l}\text { Obecność funk- } \\
\text { cji X-Ray }\end{array}$ & $\mathrm{Nie}$ & Nie & $\mathrm{Nie}$ & Tak \\
\hline $\begin{array}{l}\text { Wyraźne wyjście } \\
\text { z odtwarzacza }\end{array}$ & Tak & Tak & Tak & $\mathrm{Nie}$ \\
\hline
\end{tabular}

Źródło: opracowanie własne. 


\section{Wnioski z analizy}

Na pierwszy plan wysuwają się znaczące różnice pomiędzy odtwarzaczami należącymi do zagranicznych firm a rodzimym Playerem, który w porównaniu do konkurencji oferuje bardzo ograniczone opcje. Najlepiej w tej analizie wypadły Netflix i Amazon Prime Video, które zachowują równowagę między wizualnością a funkcjonalnością. Dobre UX jest skutkiem testowania pewnych rozwiązań. Dostawcy usług powinni więc słuchać swoich klientów i adresować ich potrzeby. Każdy produkt, każda zmiana, którą wprowadza Netflix, przechodzi przez rygorystyczny proces testowania A/B, który polega na stworzeniu eksperymentu, podczas którego uczestnicy podzieleni na grupy dostają różne wersje usługi. Po przeprowadzonym teście wyciągane są wnioski i na ich podstawie tworzony jest końcowy produkt ${ }^{38}$. HBO GO przez brak niektórych opcji nie jest tak przyjazny użytkownikowi jak dwa wymienione wcześniej serwisy. Co ciekawe, wydawać by się mogło, że nie próbuje tego naprawić. Zamiast ulepszonej wersji wprowadza kompletnie nowe platformy - jak niedostępne w Polsce HBO NOW czy HBO MAX. Początkowo te trzy wymienione serwisy miały działać równolegle, natomiast koncern WarnerMedia, właściciel HBO, zdecydował, że HBO MAX zastąpi HBO GO, a HBO NOW zmieni nazwę na $\mathrm{HBO}^{39}$. Decyzje, związane najpewniej z założeniami strategii biznesowej, dotyczą jednak wyłącznie rynku USA. HBO MAX, oprócz oferowania nowego contentu, wprowadza też odmienne od HBO GO rozwiązania z zakresu user experience, do których polscy użytkownicy nie mają dostępu.

\section{Opinie użytkowników}

UX to ludzie i ich odczucia ${ }^{40}$. Należy zatem słuchać tego, co mówią, i odpowiadać na ich potrzeby. Jednym ze sposobów, który może w tym pomóc, jest badanie i analiza komentarzy. Dzięki niej dowiadujemy się między innymi, jakie problemy zgłaszają użytkownicy, co ich frustruje, co sprawiłoby, że ich doświadczenie będzie lepsze od obecnego. W dzisiejszych czasach ludzie chętnie wyrażają swoje zdanie, oceniają, komentują, zwracają uwagę na szczegóły - zarówno te, które na korzystanie z danego serwisu wpływają negatywnie, jak i pozytywnie. Tym sposobem na podstawie krótkiej

38 https://netflixtechblog.com/its-all-a-bout-testing-the-netflix-experimentation-platform4e1ca458c15 (dostęp: 15.05.2020).

39 T. Gardziński, HBO likwiduje HBO GO i Now, a zostawia HBO Max. Co to oznacza dla Polaków?, https://www.spidersweb.pl/rozrywka/2020/06/15/hbo-max-a-hbo-go-nowa-strategia-co-w-polsce (dostęp: 22.11.2020).

40 A. Kita, op. cit. 
analizy treści, które pojawiły się w AppStore i Google Play ${ }^{41}$, wyłania się obraz tego, co odbiorcy myślą na temat rozwiązań oferowanych przez platformy streamingowe ${ }^{42}$.

Ze wszystkich czterech serwisów użytkownicy urządzeń, które działają pod kontrolą systemu operacyjnego Android, najlepiej ocenili aplikację Netflix. W wielu komentarzach chwalona jest jej funkcjonalność, intuicyjność i łatwość obsługi ${ }^{43}$. Problemy, które się pojawiały, dotyczyły między innymi: braku opcji, która pozwoliłaby na dostosowanie jakości oglądanego filmu czy samoistnie zmieniająca się jasność ekranu podczas odtwarzania ciemniejszej sceny. Inaczej sprawa wygląda w przypadku posiadaczy telefonów i tabletów firmy Apple. Według nich pierwsze miejsce zajmują ex aequo HBO GO i Amazon Prime Video. Co ciekawe, w opiniach na temat HBO GO często zauważany był brak niektórych rozwiązań z zakresu UX, które pojawiają się u konkurencji. Poruszane były takie sprawy jak nieobecność przycisku, który umożliwia przewijanie o kilka sekund do przodu, brak możliwości pomijania czołówek czy problemy związane z korzystaniem z paska postępu. Użytkownicy byli też zirytowani liczbą błędów, które przeszkadzają w komfortowym korzystaniu $\mathrm{z}$ aplikacji. Amazon Prime Video jest bardzo dobrze kojarzony za funkcję X-Ray oraz możliwość ominięcia materiałów promocyjnych. Negatywne komentarze dotyczyły raczej oferowanego contentu niż samej aplikacji. Player ma najmniej pozytywnych opinii zarówno w AppStore, jak i Google Play. Aplikacja jest mało stabilna, często się zacina, a reklamy są wyświetlane pomimo wykupionego dostępu premium, który te materiały powinien likwidować ${ }^{44}$.

\section{Podsumowanie}

Współcześnie można zaobserwować ogromną rywalizację o czas i pieniądze konsumentów. Pozytywne doświadczenie użytkownika jest więc kartą przetargową, mającą przechylić szalę zwycięstwa na stronę danego dostawcy usług. Wszystkie działania mają ostatecznie prowadzić do zdobycia jak największej liczby klientów. Będąc na rynku, który tak dynamicznie ewoluuje, nie można bowiem stać w miejscu i nie odpowiadać na potrzeby widza. Trzeba się dostosowywać, ulepszać, wprowadzać po-

${ }^{41}$ App Store i Google Play to platformy cyfrowej dystrybucji dające użytkownikom dostęp do aplikacji mobilnych.

42 Oczywiście opinie użytkowników są subiektywne, a niektóre problemy mogą wynikać z urządzeń wykorzystywanych przez odbiorców, a także innych przypadkowych sytuacji.

${ }^{43}$ Wszystkie dane pochodzą ze stron https://apps.apple.com oraz https://play.google.com/.

44 Powyżej zostały przedstawione uwagi, które autorka uważa za najważniejsze w kontekście całego artykułu. Nie sposób tu jednak wymienić i opisać wszystkich frustracji i pochwał kierowanych pod adresem osób, które zarządzają analizowanymi platformami. Jest to materiał na pogłębioną analizę, która powinna zostać przeprowadzona przez pracowników firm odpowiedzialnych za dbanie o doświadczenie swoich klientów. 
prawki tak, aby zapewnić jak najlepsze doświadczenie, idące w parze z oferowanym produktem. Można jednak odnieść wrażenie, że tylko niektórzy producenci to rozumieją. Pozostali nie radzą sobie z tym tak dobrze. Powinni więc mieć na uwadze nowe platformy, które wchodzą do Polski, takie jak Apple TV czy Disney+. Jeśli te firmy, oprócz zachęcających treści, będą oferować klientom wysoki poziom doświadczenia, to mogą wygrać walkę o subskrybentów.

Należy się również zastanowić, czy płynące w szybkim tempie codzienne życie nie zmienia potrzeb i nawyków konsumenckich. Uwaga jest dziś dobrem deficytowym, ograniczonym, bo każdy ma jej skończoną pulę. Z jednej strony dalej można obserwować występowanie zjawiska znanego jako binge-watching, a z drugiej - znalezienie czasu i chęci, żeby przesiedzieć w miejscu godzinę, patrząc w ekran urządzenia (szczególnie po całym dniu pracy przed komputerem), zaczyna być coraz trudniejsze. Zauważono to $\mathrm{w}$ Japonii, która jest miejscem narodzin Cell phone novel ${ }^{45}$, czyli bardzo krótkich opowiadań, które czyta się jak wiadomość. Przeciętny rozdział ma nie więcej niż 100 słów i tym samym doskonale nadaje się do przeczytania choćby w trakcie przejazdu środkami komunikacji.

Dodatkowo w kwietniu 2020 roku swój start miała amerykańska mobilna platforma wideo Quibi ${ }^{46}$. Nazwa usługi powstała od angielskich słów quick bites, czyli „małe urywki”. Z uwagi na pandemię nie był to najszczęśliwszy okres, żeby wejść na rynek, ponieważ założeniem Quibi jest dostarczanie treści specjalnie zaprojektowanych na urządzenia mobilne (oferuje możliwość oglądania w trybie portretowym), tak aby można je było oglądać poza domem. Zamiast czterdziestopięciominutowych odcinków serialu czy dwugodzinnych filmów Quibi oferuje materiał trwający maksymalnie dziesięć minut. Tym samym można go obejrzeć $\mathrm{w}$ tramwaju, w kolejce do lekarza czy w przerwie w pracy.

Podsumowując niniejszą, krótką analizę, należy wskazać, że bogaty oraz różnorodny content często wydaje się niewystarczający. Aby wygrać uwagę użytkownika, potrzebne jest dobrze zaprojektowane doświadczenie, które widz otrzyma razem z usługą. Warto również na koniec postawić sobie pytanie: dokąd właściwie zmierza sektor oferujący rozrywkę i czy idzie w tę samą stronę, w którą jego potencjalni użytkownicy?

\section{Bibliografia}

Babich N., 7 basic rules for button design, https://uxplanet.org/7-basic-rules-for-button-design-63dcdf5676b4 (dostęp: 20.07.2020).

Bednarzewski M., Ewolucja postaw konsumentów w Polsce wobec sposobów korzystania z rozrywki filmowej, [w:] Kreatywność i innowacyjność w erze cyfrowej, red. A. Zorska, M. Molęda-Zdziech, B. Jung, Warszawa 2014, s. 175-197.

45 https://en.wikipedia.org/wiki/Cell_phone_novel (dostęp: 15.05.2020).

${ }^{46}$ https://quibi.com (dostęp: 15.05.2020). 
Bryl N., Streaming w kulturze - uwagi wstępne, „Studia ad Bibliothecarum Scientiam Pertinentia” 2018, nr 16, s. 129-138.

Evans H., Content is king - essay by Bill Gates 1996, https://medium.com/@HeathEvans/content-isking-essay-by-bill-gates-1996-df74552f80d9 (dostęp: 12.05.2020).

Gardziński T., HBO likwiduje HBO GO i Now, a zostawia HBO Max. Co to oznacza dla Polaków?, https:// www.spidersweb.pl/rozrywka/2020/06/15/hbo-max-a-hbo-go-nowa-strategia-co-w-polsce (dostęp: 22.11.2020).

Golińska-Konecko M., Stare media wobec nowych technologii. Ewolucja telewizji w Polsce, „Zeszyty Naukowe Gdańskiej Szkoły Wyższej" 2018, nr 3, s. 195-206.

Groenewegen A., Kahneman fast and slow thinking explained, https://suebehaviouraldesign.com/kahne man-fast-slow-thinking (dostęp: 12.05.2020).

Inglis B.D., Couples G.D., John Logie Baird and the secret in the box: The undiscovered story behind the world's first public demonstration of television, „Proceedings of the IEEE” 2020, nr 108, s. 1371-1382.

Janowska A., Przemysł kultury w erze dostępu, „Kolegium Zarządzania i Finansów. Zeszyt Naukowy” 2017, nr 158, s. 179-199.

Kita A., Dlaczego Customer Experience to nie User Experience?, https://www.thinkle.pl/2019/08/27/ dlaczego-cx-to-nie-ux/ (dostęp: 22.11.2020).

Krug S., Don't Make Me Think, Revisited: A Common Sense Approach to Web Usability, [bmw] 2013.

Levinson M., Netflix: Winning moments of truth?, https://medium.com/@maxlevinson/netflix-winningmoments-of-truth-113cc7884909 (dostęp: 13.05.2020).

Michalik Ł., 120 lat kina. Jak zmieniała się technologia, dzięki której oglądamy filmy?, https://gadzetomania.pl/57136,120-lat-kina-jak-zmieniala-sie-technologia-dziekiktorej-ogladamy-filmy (dostęp: 12.05.2020).

Narodziny techniki filmowej i kinowej, https://www.historiasztuki.com.pl/strony/01500-01-FILM-TE CHNIKA.html (dostęp: 13.05.2020).

National Science and Media Museum, A very short history of cinema, https://blog.scienceandmediamuseum.org.uk/very-short-history-of-cinema (dostęp: 13.05.2020).

Nyziak A., Jak niewidomi oglądaja filmy, http://swiatlekarza.pl/niewidomi-ogladaja-filmy (dostęp: 14.05.2020).

Pogorzelski J., Momenty prawdy i punkty kontaktu, http://jacekpogorzelski.pl/momenty-prawdy-i-punkty-kontaktu (dostęp: 13.05.2020).

PwC, Streaming ahead. Making UX + content strategy work together, https://www.pwc.com/us/en/services/consulting/library/pdf/2019-tmt-cis-content-is-king.pdf (dostęp: 11.05.2020).

PwC, Wideo: więcej, szybciej, lepiej. Jak cyfrowa rewolucja zmienia rynek treści wideo, https://www.pwc. pl/pl/pdf/pwc-raport-wideo-2017.pdf (dostęp: 11.05.2020).

Raphael R., Netflix CEO: Reed Hastings: Sleep is our competition, https://www.fastcompany. com/40491939/netflix-ceo-reed-hastings-sleep-is-ourcompetition (dostęp: 12.05.2020).

Rice L., Content is king, but UX is queen, https://www.linkedin.com/pulse/contentking-ux-queen-elizabeth-rice (dostęp: 11.05.2020).

Sztąberek M., Platforma strumieniowa Netflix - domena VOD czy nowa forma telewizji jakościowej? Historia i sposoby dystrybucji, „Panoptikum” 2018, nr 20, s. 10-32.

The Pathfinders, 6 głównych obszarów User Experience - czym jest UX Kompas? https://medium.com/@ thepathfinderspl/ux-kompas-1f449b67d860 (dostęp: 12.05.2020).

Urban S., Sreenivasan R., Kannan V., It's all A/Bout testing: The Netflix experimentation platform, https:// netflixtechblog.com/its-all-a-bout-testing-the-netflix-experimentation-platform-4e1ca458c15 (dostęp: 15.05.2020).

Urbański A., Dziewa L., Tworzenie doświadczeń klientów, Gliwice 2020.

Dziennikarstwo i Media 13, 2020

(C) for this edition by CNS 


\section{User experience in the streaming era - a comparative analysis of VoD services available on the Polish market}

Summary

For the last couple of years streaming services have been taking part in a race, in which the user's attention and subscription are the prizes. In today's world entertainment offers are being thrown at users from all sides. They do not have the time needed to check them all. Competition in this segment is enormous. It is not about providing a wide variety of movies, TV series or programmes anymore. To gain viewers' loyalty, you need to ensure the best possible experience of using a product. The aim of this article is therefore to analyze and compare the elements of UX used in video players of platforms such as Netflix, HBO GO, Amazon Prime Video, and Player.

Keywords: streaming services, user experience, mobile apps, video players, subscription 